University of Vermont

UVM ScholarWorks

Rubenstein School of Environment and Natural Rubenstein School of Environment and Natural Resources Faculty Publications

Resources

$1-1-2014$

\title{
Whales as marine ecosystem engineers
}

Joe Roman

University of Vermont

James A. Estes

University of California, Santa Cruz

Lyne Morissette

Craig Smith

University of Hawai'i at Mānoa

Daniel Costa

University of California, Santa Cruz

See next page for additional authors

Follow this and additional works at: https://scholarworks.uvm.edu/rsfac

Part of the Climate Commons, Community Health Commons, Human Ecology Commons, Nature and Society Relations Commons, Place and Environment Commons, and the Sustainability Commons

\section{Recommended Citation}

Roman J, Estes JA, Morissette L, Smith C, Costa D, McCarthy J, Nation JB, Nicol S, Pershing A, Smetacek $V$. Whales as marine ecosystem engineers. Frontiers in Ecology and the Environment. 2014

Sep;12(7):377-85.

This Article is brought to you for free and open access by the Rubenstein School of Environment and Natural Resources at UVM ScholarWorks. It has been accepted for inclusion in Rubenstein School of Environment and Natural Resources Faculty Publications by an authorized administrator of UVM ScholarWorks. For more information, please contact scholarworks@uvm.edu. 


\section{Authors}

Joe Roman, James A. Estes, Lyne Morissette, Craig Smith, Daniel Costa, James McCarthy, J. B. Nation, Stephen Nicol, Andrew Pershing, and Victor Smetacek 


\section{Whales as marine ecosystem engineers}

Joe Roman $^{1 *}$, James A Estes ${ }^{2}$, Lyne Morissette ${ }^{3}$, Craig Smith ${ }^{4}$, Daniel Costa ${ }^{2}$, James McCarthy ${ }^{5}$, JB Nation ${ }^{6}$, Stephen $\mathrm{Nicol}^{7}$, Andrew Pershing ${ }^{8,9}$, and Victor Smetacek ${ }^{10}$

Baleen and sperm whales, known collectively as the great whales, include the largest animals in the history of life on Earth. With high metabolic demands and large populations, whales probably had a strong influence on marine ecosystems before the advent of industrial whaling: as consumers of fish and invertebrates; as prey to other large-bodied predators; as reservoirs of and vertical and horizontal vectors for nutrients; and as detrital sources of energy and habitat in the deep sea. The decline in great whale numbers, estimated to be at least $66 \%$ and perhaps as high as $90 \%$, has likely altered the structure and function of the oceans, but recovery is possible and in many cases is already underway. Future changes in the structure and function of the world's oceans can be expected with the restoration of great whale populations.

Front Ecol Environ 2014; 12(7): 377-385, doi:10.1890/130220 (published online 3 Jul 2014)

$\mathrm{T}$ here is mounting evidence that apex predators play important roles in the workings of natural ecosystems (Estes et al. 2011; Smith et al. 2013). Ocean science has been slow to embrace this view for at least three interrelated reasons: (1) following World War II, when oceanographic research gained new impetus, most whale populations had been depleted or were in steep decline, so that ocean scientists had little opportunity to study oceans with natural stocks of large predators, especially great whales; (2) there are logistical and operational challenges in studying large mobile animals on the high seas, with manipulative experiments being all but impossible (Bowen 1997); and (3) the prevailing focus of ocean science has been on bottom-up controls, such as resource limitation and physical factors such as temperature (Baum and Worm 2009). This review synthesizes our

\section{In a nutshell:}

- Commercial whaling dramatically reduced the biomass and abundance of great whales and, until recently, we have lacked the ability to study and directly observe the functional roles of whales in marine ecosystems

- Whales facilitate the transfer of nutrients by releasing fecal plumes near the surface after feeding at depth and by moving nutrients from highly productive, high-latitude feeding areas to low-latitude calving areas

- Whale carcasses sequester carbon to the deep sea, where they provide habitat and food for many endemic invertebrates

- The continued recovery of great whales may help to buffer marine ecosystems from destabilizing stresses and could lead to higher rates of productivity in locations where whales aggregate to feed and give birth

${ }^{1}$ Gund Institute for Ecological Economics, University of Vermont, Burlington, VT *(jroman@uvm.edu); ${ }^{2}$ Department of Ecology and Evolutionary Biology, University of California, Santa Cruz, Santa Cruz, CA; ${ }^{3} \mathrm{M}$ Expertise Marine, Sainte-Luce, Canada; ${ }^{4}$ Department of Oceanography, University of Hawaii at Manoa, Honolulu, HI (continued on p 385) emerging understanding of the ecological role of great whales, a group - largely defined by size and commercial history - that includes all baleen whales (Mysticeti) and the sperm whale (Physeter macrocephalus). The terms whales and great whales are used interchangeably in this text. Even though the large body size, great historical abundance, high metabolic demands, and broad global distribution of whales is well known, we propose that the ecological role of these animals has been undervalued because we have underestimated the degree to which the depletion of great whales caused by a worldwide commercial harvest has altered marine ecosystems.

The earliest records of commercial whaling date from approximately $1000 \mathrm{CE}$, when the Basque people began hunting North Atlantic right whales (Eubalaena glacialis). In the millennium that followed, whaling systematically depleted coastal whale species, followed by reductions of pelagic species as well (Tønnessen and Johnsen 1982). Although the overall level of reduction is still debated, experts agree that tens of millions of whales were killed during the thousand-year period of commercial whaling. Estimates of numerical declines range from $66 \%$ to $90 \%$ of populations, and total whale biomass may have been reduced by an estimated $85 \%$ (Branch and Williams 2006; Christensen 2006). For many species, population reductions were even more extreme: blue whales (Balaenoptera musculus), for example, have been reduced to $1 \%$ of their historical numbers in the Southern Hemisphere (Christensen 2006). Analyses of genetic diversity suggest that historical populations of several species, including North Atlantic humpback whales (Megaptera novaeangliae) and fin whales (Balaenoptera physalus), in addition to Pacific gray whales (Eschrichtius robustus), were larger than previously supposed (Roman and Palumbi 2003; Alter et al. 2007; Ruegg et al. 2013). This genetic approach indicates that the depletion of the great whales may be in the range of $90 \%$ or greater.

Whales were once almost exclusively valued as goods to be removed from the ocean: for meat, oil (fuel, lubrication, and the manufacture of nitroglycerine), baleen (or 


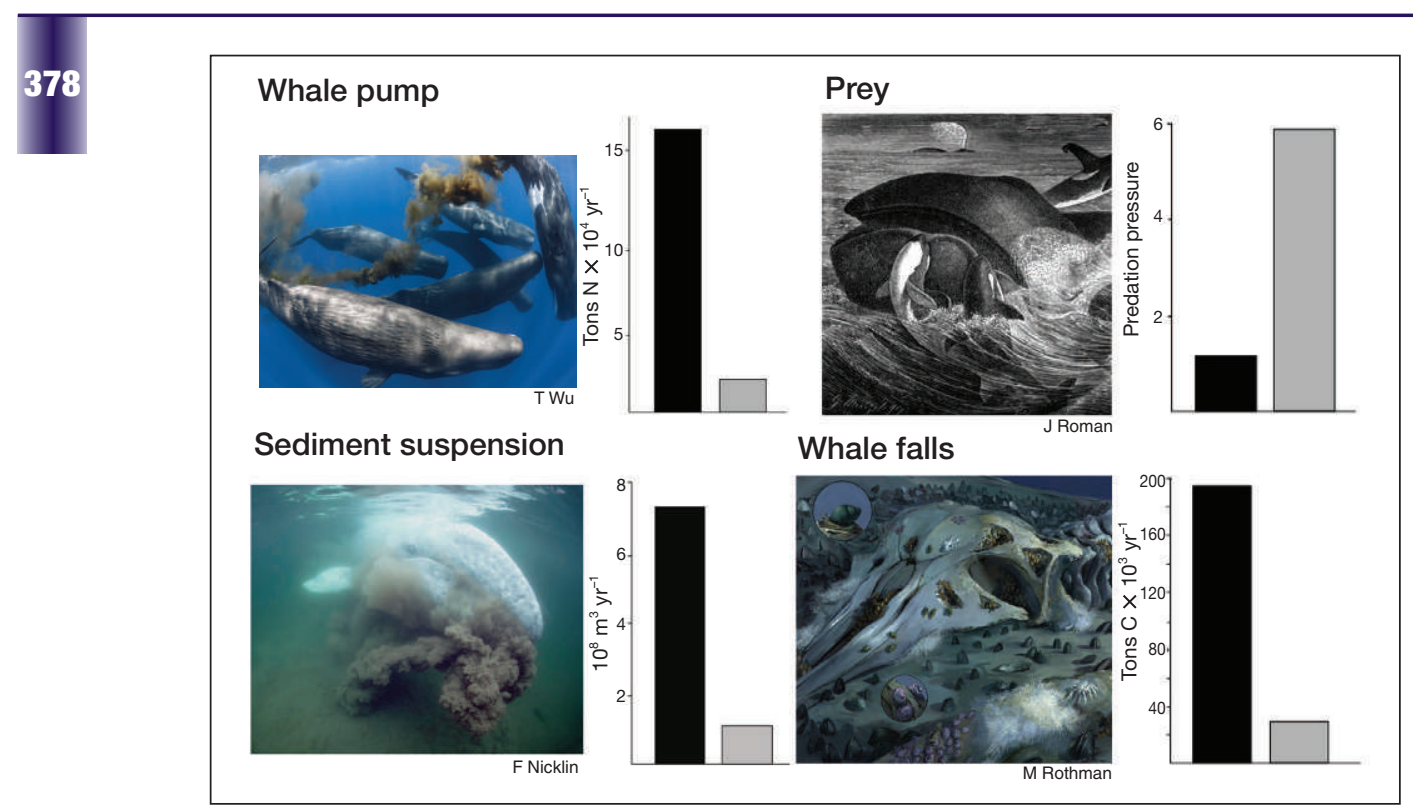

Figure 1. Examples of the influence of whales on diverse ecosystem functions. Black bars represent estimated pre-whaling contributions; gray bars show contributions from currently estimated populations. Data for gray whales (Eschrichtius robustus) ("Sediment suspension"), "Whale pump" (N released at the surface in the Gulf of Maine), and "Whale falls" (C exported to sea floor) are from original sources (Alter et al. 2007; Pershing et al. 2010; Roman and McCarthy 2010). Predation pressure is measured as the biomass of killer whales per unit biomass of available marine mammal prey, calculated from estimates of abundance for all available marine mammal prey, including great whales, small cetaceans, pinnipeds, and sea otters for the North Pacific Ocean and Bering Sea before and after industrial whaling (Pfister and DeMaster 2006) and assuming that killer whale numbers have remained the same. As a result of these changes in abundance, the risk of predation has increased for great whales and prey availability has declined for killer whales. Although standard errors are not available for these estimates, there is uncertainty in the number of whales before and after commercial exploitation and the contribution of $\mathrm{N}$ and $\mathrm{C}$ for the whale-pump and whale-fall calculations.

whalebone, prized for its flexibility and strength), and spermaceti (a waxy substance found in the head cavities of sperm whales that was used in candles, ointments, and industrial lubricants). They are now increasingly valued for the many ecosystem services they provide. Great whales can exert major trophic influences on marine ecosystems and also act as ecosystem engineers (Jones and Gutierrez 2007), influencing material fluxes and species diversity and causing physical changes to the ocean environment (Table 1). These functions will become increasingly relevant to ocean restoration and management as great whale populations continue to recover in the postwhaling era (Magera et al. 2013; Roman et al. 2013).

In this paper, we describe and discuss four mechanisms or ecological pathways by which whales influence marine ecosystems - as consumers, prey, detritus, and nutrient vectors (Figure 1) - and identify the associated ecosystem services.

\section{Whales as consumers}

Whales can exert strong pressures on marine communities through direct predation and indirect food-web interactions. At a regional scale, the potential influence of whales as consumers is considerable; for instance, an estimated $65 \%$ (range $53-86 \%$ ) of the North Pacific Ocean's primary production was required to sustain the large whale populations prior to commercial whaling (Croll et al. 2006). There is evidence that whales were similarly abundant elsewhere, so this calculation may have applied to temperate oceans generally. Lacking whales, this productivity is now shunted to other species and food-web pathways, though arguably primary production may have been higher in the past because of whaleinduced recycling and upperocean retention of nutrients (Roman and McCarthy 2010). Although as an endotherm a whale's total metabolic rate is high, one consequence of its immense size is a low mass-specific metabolic rate relative to smaller animals. The amount of food required to sustain one blue whale could support seven smaller minke whales (Balaenoptera acutorostrata) or 1500 penguins, but the higher metabolic rates of these smaller animals would limit their collective biomass to just $50 \%$ or $8 \%$, respectively, of a blue whale's biomass. With primary production held constant, reducing baleen whale populations lowers the potential for marine ecosystems to retain carbon (C), both in living biomass and in carcasses that sink to the ocean floor (Pershing et al. 2010).

As major predators in many marine ecosystems, whales can influence the ecological and evolutionary dynamics of prey populations, with effects propagating through food webs and biogeochemical cycles, such as the transport of nitrogen $(\mathrm{N})$ and iron $(\mathrm{Fe})$. Predation by baleen whales, for example, may have been an important evolutionary force on Calanus copepods in the Arctic, selecting for shorter life spans, smaller size, and higher growth rates; now that whales are functionally extinct in much of this region, selection is favoring longer-lived, larger copepod species (Berge et al. 2011). The near-extirpation of whales from the Southern Ocean in the 20th century may have released other krill predators, such as penguins and Antarctic fur seals (Arctocephalus gazella), from competition (Ballance et al. 2006).

Whales and other marine mammals have often been implicated in declines in fish populations, resulting in conflicts with human fisheries (Lavigne 2003), yet there is limited direct evidence for such competition. In the 
Caribbean, for instance, whales and humans consume largely different resources. Furthermore, in ecosystem models where whale abundances were reduced, fish stocks showed appreciable decreases, and in some cases the presence of whales in these models resulted in improved fishery yields (Morissette et al. 2010). Consistent with these findings, several models have shown that alterations in marine ecosystems resulting from the removal of whales and other marine mammals do not lead to increases in human fisheries (Morissette et al. 2012). Rather than reducing fishery yields, the presence of some species, such as blue whales in the Southern Ocean, promotes productivity through the defecation of nutrient-rich feces (Lavery et al. 2014).

Apollonio (2002) postulated that the presence of $K$ selected species, which tend to be long lived and density dependent, can provide stability in the system; whales, as one of the longer-lived species in marine systems, can dampen the frequency and amplitude of oscillations caused by perturbations in climate, predation, and primary productivity. As density-dependent species have been removed from marine communities, there is evidence that systems dominated by $r$-selected species, or those that are short lived and density independent, are less predictable, more vulnerable to exogenous stressors, and more difficult to manage (Apollonio 2002). Although whales themselves may be expected to increase stress on prey during years of low primary productivity, they will also likely move to other feeding areas.

When foraging, whales can influence the ocean's local physical environment. Diving and surfacing whales can enhance the upward transport of nutrient-rich deep water as they pass through density gradients during feeding sessions (Dewar et al. 2006). Humpback whales create spiral flow features using underwater exhalations to concentrate their prey; these "bubble nets" may be the most ephemeral of engineered physical constructs (Hastings et al. 2007). Humpback whales also intentionally disturb the sand and shell-hash (a mix of mud, sand, and broken shells) sea bottom to flush sand-lance prey from their burrows (Hain et al. 1995). The plowing of meter-wide gouges in the Bering Sea floor by gray whales foraging for amphipods can affect benthic topography for centuries (Nelson and Johnson 1987). This bottom-feeding behavior also causes substantial amounts of sediment and nutrients to become suspended in the water column, enhancing nutrient recycling and bringing some benthic crustaceans to the ocean surface, an activity that provides food for surface-feeding seabirds (Alter et al. 2007).

\section{Whales as prey}

Whales, by virtue of their large size, concentrate energy and nutrients in ocean environments where these resources are otherwise highly dispersed and often limiting. Although very large body size is a deterrent to predation in most ecosystems (Sinclair et al. 2003), the marine realm contains species of large predators that are fully capable of subduing great whales. Examples from earlier times include Carcharocles megalodon, a giant shark with serrated teeth, and large raptorial cetaceans (Lambert et al. 2010). Numerous historical accounts, artistic representations, and contemporary reports of killer whales (Orcinus orca) attacking great whales, and the high fre-

\begin{tabular}{|c|c|c|}
\hline Mechanism & Result & References \\
\hline $\begin{array}{l}\text { Physical engineering } \\
\text { eg benthic plowing by gray whales; } \\
\text { diving to feed at or beneath the thermocline; } \\
\text { humpback whales making bubble nets }\end{array}$ & $\begin{array}{l}\text { - Enhanced benthic-pelagic coupling (eg nutrient } \\
\text { regeneration); altered seafloor microtopography } \\
\text { (timescale: up to hundreds of years) } \\
\text { - Ocean mixing (timescale: hours) } \\
\text { - Ephemeral alteration of water column } \\
\text { (timescale: seconds) }\end{array}$ & $\begin{array}{l}\text { Nelson and Johnson (1987); } \\
\text { Dewar et al. (2006); } \\
\text { Hastings et al. (2007) }\end{array}$ \\
\hline $\begin{array}{l}\text { Vertical and horizontal nutrient transfer } \\
\text { Whale pump: Fe released in fecal } \\
\text { plumes, } \mathrm{N} \text { released in urine and fecal plumes; } \\
\text { Great whale conveyor belt: nutrients transferred } \\
\text { through urea, carcasses, and placentas from } \\
\text { areas of high to low productivity during whale } \\
\text { migration }\end{array}$ & $\begin{array}{l}\text { - Enhanced productivity and abundance of prey; } \\
\text { extended phytoplankton blooms; C sequestration } \\
\text { - Transfer of nutrients from areas of high to low } \\
\text { productivity }\end{array}$ & $\begin{array}{l}\text { Lavery et al. (20I0); } \\
\text { Roman and McCarthy (20I0) }\end{array}$ \\
\hline $\begin{array}{l}\text { Food-web interactions, including trophic } \\
\text { cascades }\end{array}$ & $\begin{array}{l}\text { - The loss of great whales precipitated a trophic cascade } \\
\text { that affected many species, including sea otters, kelp } \\
\text { forests, fish nurseries, and birds of prey }\end{array}$ & $\begin{array}{l}\text { Springer et al. (2003); } \\
\text { Reisewitz et al. (2006); } \\
\text { Wilmers et al. (2012) }\end{array}$ \\
\hline Hierarchical ecosystem structure & - Enhanced stability and predictability of the ecosystem & Apollonio (2002) \\
\hline Whale falls and strandings & $\begin{array}{l}\text {-Whale falls (a) provide a massive pulse of organic } \\
\text { enrichment to the deep sea, typically greater than } \\
2000 \text { years of average } C \text { flow to sediments } \\
\text { underlying the carcass; and (b) provide habitat } \\
\text { structure and food resources for many endemic } \\
\text { species, including chemosynthetic bacteria and } \\
\text { invertebrate hosts } \\
\text { - Stranded whales can subsidize terrestrial food webs }\end{array}$ & $\begin{array}{l}\text { Chamberlain et al. (2005); } \\
\text { Smith (2006) }\end{array}$ \\
\hline
\end{tabular}



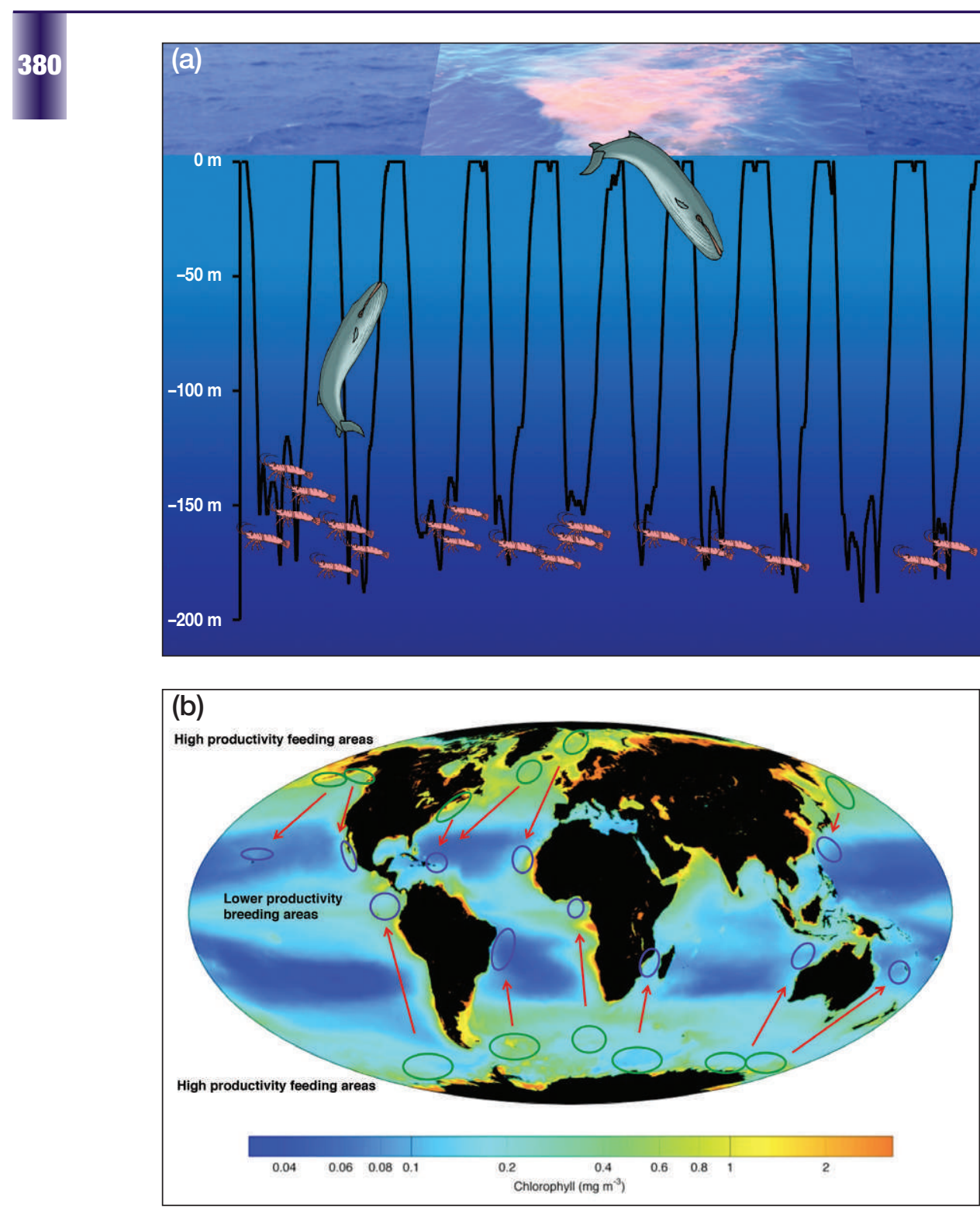

Figure 2. Whales provide highly mobile nutrient subsidies in the oceans, both (a) vertically and (b) horizontally, and on local and global scales. (a) Dive pattern for a blue whale in the North Pacific Ocean, based on Croll et al. (2005). Inset at top, blue whale feces; photo courtesy of $\mathrm{H}$ Ryono/Aquarium of the Pacific. (b) Representative global migration patterns for humpback whales, exhibiting the movement (red arrows) from high-latitude feeding grounds (green ovals) to lowlatitude breeding grounds (blue ovals). Feeding and breeding areas are approximate and do not include all groups. Distribution of humpback whales is based on Reilly et al. (2008).

quency of scrapes and rake marks on the flukes of most large whale species, affirm a long-standing and widespread utilization of whales as prey (Springer et al. 2003).

Because whales are important prey for killer whales, the removal of great whales likely had a broad array of indirect effects. Approximately 10\% of the estimated 50000 killer whales worldwide today appear to feed exclusively on marine mammals (Forney and Wade 2006; Reeves et al. 2006). Following the depletion of great whales, their killer whale predators must have either declined in abundance or expanded their diet to include other prey species (Estes et al. 2009). In the North Pacific Ocean, killer whales purportedly began to feed more extensively on smaller marine mammals, such as harbor seals (Phoca vitulina), Steller sea lions (Eumetopias jubatus), and sea otters (Enhydra lutris), with consequent decreases in these populations (Springer et al. 2003, 2008). The loss of sea otters released herbivorous sea urchins (the otter's preferred prey) from limitation by predation, causing an increase in their rate of herbivory and a decline of coastal kelp forests (Estes et al. 1998). Based on evidence obtained from the Aleutian archipelago and elsewhere in the North Pacific Ocean, kelp forest declines led to reductions in primary productivity, coastal fish populations, and a decrease in the marine sequestration of $\mathrm{C}$ (Reisewitz et al. 2006; Markell 2011; Wilmers et al. 2012). Follow-on effects from the pinniped declines are less well known; pinnipeds in the North Pacific Ocean prey on finfish such as cod (Gadus spp), which themselves prey on smaller forage fish and neritic and benthic crustaceans. The pinniped collapse may have caused or contributed to an ecosystem shift - from crustacean dominance before to finfish dominance after the collapse (Estes et al. 2013). Of course, other forces were in play as well, including otter harvesting for the fur trade, but clearly the interaction between killer whales and their great whale prey influences the structure and function of ocean ecosystems in diverse and often unexpected ways.

\section{Whales as vectors of nutrient and material flux}

Several papers contend that whales and other air-breathing vertebrates contribute to primary production through the vertical mixing, horizontal transfer, and recycling of $\mathrm{C}$ and limiting nutrients in the ocean (see Figure 2; Lavery et al. 2010; Roman and McCarthy 2010; Smith et al. 2013). When diving to feed, whales contribute mechanical energy to the ocean (Dewar et al. 2006); this mixing effect can be especially important in stratified conditions or when there is little wind. Whales can also transport nutrients to surface waters by releasing fecal plumes and urine in their feeding areas, as they respire, digest, metabolize, or rest at or near the ocean surface (Roman and McCarthy 2010). This "whale pump" likely plays a role in enhancing productivity in biological hotspots (ie regions 
of high primary productivity that are associated with rich and diverse upper trophic levels). Field examinations in these regions will be especially valuable in determining the relative contribution of whale activity in comparison to other processes, such as upwelling and nutrient flux due to wind mixing and internal, or gravity, waves that occur beneath the ocean surface.

In many marine systems, $\mathrm{N}$ is the primary limiting macronutrient (Rabalais 2002). Studies in the Gulf of Maine show that cetaceans and other marine mammals deliver large amounts of $\mathrm{N}$ to the photic zone by feeding at or below the thermocline and then excreting urea and metabolic fecal $\mathrm{N}$ near the surface (Roman and McCarthy 2010). Ammonium concentrations in fecal plumes are several orders of magnitude higher than ambient levels in surrounding waters; Roman and McCarthy (2010) hypothesized that this released $\mathrm{N}$ enhances local plankton productivity.

In the Southern Ocean, primary production is limited by Fe availability (Smetacek et al. 2012). Sperm whales, feeding on deep-living prey and defecating at the surface, facilitate the upward transport of Fe into the photic zone. When producing blubber, whales assimilate little of their dietary Fe, and their fecal plumes have an Fe concentration at least 10 million times greater than ambient levels (Nicol et al. 2010). If the resulting new primary production is transported to the deep sea by sinking phytoplankton blooms, one study suggests that this could result in the export of at least 200000 tons $\mathrm{C} \mathrm{yr}^{-1}$ from the atmosphere to the deep ocean (Lavery et al. 2010). This study used a population size of 12000 sperm whales in the Southern Ocean, which may be an underestimate (Whitehead 2002). More whales would mean more Fe released at the surface. Current populations of krill contain about $24 \%$ of the total $\mathrm{Fe}$ in the upper $200 \mathrm{~m}$ of the Southern Ocean (Nicol et al. 2010). These crustaceans are strong swimmers with long lives (5-7 years); unlike detritus and inorganic particles, which tend to sink, krill can act as a buoyant reservoir of Fe.

Contrary to the expectation that krill stocks would increase with the decimation of Southern Ocean whale populations, many areas of the ocean have shown no noticeable increase, and stocks may even have declined in some locations (Lee et al. 2010). The lack of increase could have been caused or facilitated by the reduction of whale-contributed Fe fertilization needed for primary productivity, a condition that may in turn hinder the recovery of some whale populations through negative feedbacks. A recent study of the growth response of three species of marine phytoplankton to pygmy blue whale (Balaenoptera musculus brevicauda) feces demonstrated clear dose-dependent stimuli to photosynthesis and increased growth rates for two phytoplankton species, supporting the role of whales in marine nutrient cycling (Smith et al. 2013).

Great whales may also figure in the horizontal transport of limiting nutrients and other essential materials across large ocean areas. The migration of baleen whales between high-latitude feeding and low-latitude calving grounds is among the farthest annual movements of mammals (Rasmussen et al. 2007). For example, humpback whales in the Northern Hemisphere migrate from feeding grounds along the coastal regions of Alaska to breeding grounds near Hawaii and Mexico; in the Southern Hemisphere, they migrate from feeding grounds off Antarctica to calving grounds off the coasts of Australia, the South Pacific islands, South America, and Africa (Figure 2b). Whales usually fast while in these winter calving grounds and use up lipid reserves for maintenance metabolism and, in the case of females, for milk production; they release $\mathrm{N}$ in the form of urea into typically oligotrophic tropical or subtropical waters. Using an analogy from other marine mammals (Costa 2009) and assuming that protein catabolism scales to metabolic rate as mass ${ }^{0.75}$, we estimate that a fasting 105 -ton blue whale excretes $450 \mathrm{~g} \mathrm{~N}$ day $^{-1}$, and a lactating female of similar size excretes $3300 \mathrm{~g} \mathrm{~N}$ day $^{-1}$ (see WebPanel 1). Employing pre- and post-whaling abundances and population size structures from Pershing et al. (2010) and assuming 15\% of the animals were lactating, we estimate that blue whales currently transport $\sim 88$ tons $\mathrm{N} \mathrm{yr}^{-1}$ to their lowlatitude calving grounds. Before commercial whaling began, blue whales would have transported $\sim 24000$ tons $\mathrm{N} \mathrm{yr}^{-1}$ from the $\mathrm{N}$-rich Southern Ocean to the comparatively nutrient-poor lower-latitude oceans, potentially allowing phytoplankton to fix an additional 140000 tons

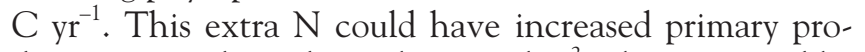
ductivity in a hypothetical $\sim 6000-\mathrm{km}^{2}$ calving ground by $26 \mathrm{~g} \mathrm{C} \mathrm{m}^{-2} \mathrm{yr}^{-1}$, a $15 \%$ increase above the $\sim 150 \mathrm{~g} \mathrm{C} \mathrm{m}^{-2}$ $\mathrm{yr}^{-1}$ average for subtropical waters (Yool et al. 2007). Considering that many other baleen whale species conduct similar reproductive migrations, the transfer of $\mathrm{N}$, in the form of excreted urea and other nutrients in placentas and carcasses, forms a "great whale conveyor belt", which might substantially enhance productivity in lower-latitude breeding areas as whale populations recover.

\section{Whale falls}

The carcasses of great whales are the largest form of detritus to fall from the ocean surface (Smith 2006). Consisting largely of proteins and lipids, dead whales typically sink to the seafloor, yielding massive pulses of organic enrichment to a realm that is often nutrient and energy impoverished. A 40-ton gray whale, for instance, contains approximately 2 million g $\mathrm{C}$, equivalent to $>2000$ years of background C flux to the area underlying the carcass (Smith 2006).

Whale falls influence the deep-sea floor in a manner analogous to tree falls in forests, by altering local food availability, providing habitat structure, and supporting diverse biotic assemblages (Lundsten et al. 2010). Carcasses in the North Pacific typically undergo ecological succession, passing through the following stages: (1) a mobile-scavenger 


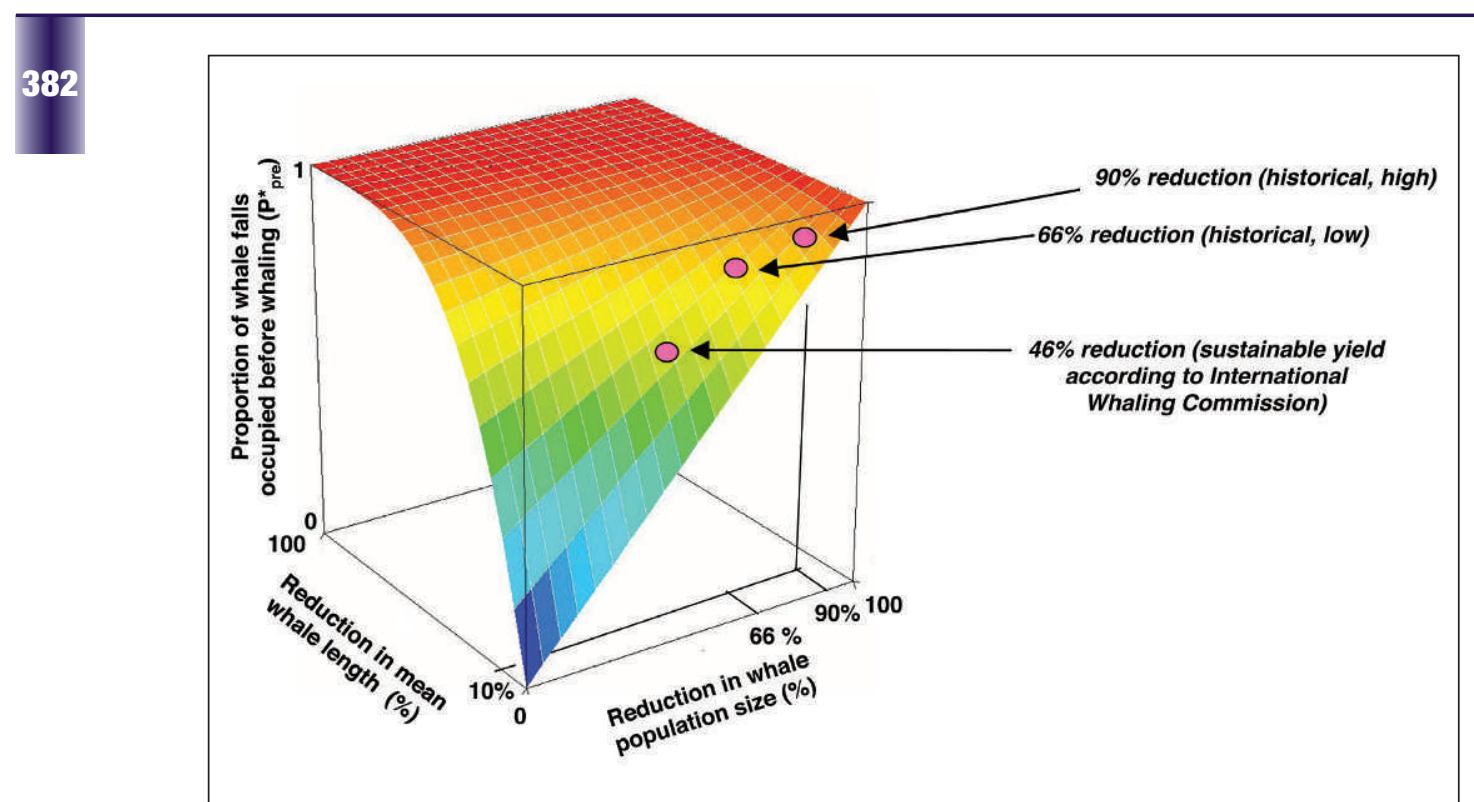

Figure 3. Extinction surface of macrofaunal species dependent on whale falls, based on Levins metapopulation model and the proportion of whale falls occupied before whaling; a species falling on or below the surface goes extinct (see WebPanel 1, Whale-fall extinctions). Species that did not occupy at least $80 \%$ of carcasses prior to whaling are likely to go extinct after intense commercial whaling, assuming whale populations have been reduced by $66 \%$ (a conservative or low estimate) and mean whale body size reduced by 10\%. (If populations were reduced by $90 \%$, the number of extinctions is higher.) Species with low whale occupancy rates prior to whaling (blue) are at highest risk of extinction.

stage, during which soft tissues are consumed by sharks, hagfish, and other necrophages; (2) an enrichment-opportunist stage, in which heterotrophic infauna exploit organically enriched sediments and lipid-rich bones; and (3) a sulphophilic stage, which can last for decades, during which sulfides derived from anaerobic decomposition of the remaining skeleton support free-living and endosymbiotic chemoautotrophic bacteria (Smith 2006; Lundsten et al. 2010; Amon et al. 2013). More than 200 macrofaunal species can inhabit a single skeleton during the sulphophilic stage (Baco and Smith 2003; Lundsten et al. 2010).

The persistent, food-rich conditions and widespread occurrence of whale falls has led to ecological and evolutionary opportunity on the deep-sea floor, in a manner similar to that of hydrothermal vents and cold seeps (Smith 2006). In the North Pacific, more than 60 macrofaunal species have been associated only with whale falls (WebTable 1). Although pelagic whaling may have initially increased the number of carcasses reaching the deepsea floor (Tønnessen and Johnsen 1982), later onboardship processing and serial depletion of populations have resulted in a reduction in numbers of such remains (Smith 2006). In the North Atlantic, where great whales have been commercially hunted for a millennium, whale populations appear to have been reduced to $<25 \%$ of prewhaling levels (Roman and Palumbi 2003), with species such as bowhead (Balaena mysticetus) and right whales becoming functionally extinct in many areas; some specialized whale-fall species probably went extinct as a result of commercial whaling. Indeed, some of the earliest anthropogenic species extinctions in the ocean may have occurred because of habitat loss for obligate whale-fall species (Figure 3). Less common species are likely to go extinct as a result of major reductions in whale carcass abundance because their ecological characteristics - such as reproductive output, dispersal and colonization ability, and susceptibility to competitive exclusion - may require a higher abundance of whale falls. In regions such as the North Pacific, where whale depletions have been more recent, the extirpation of whale-fall specialists may be less advanced. Even maintaining great whale populations at the sustainable yield levels determined by the International Whaling Commission (IWC) is likely to cause whalespecialist extinctions.

Molecular and morphological studies indicate that whalebone fauna, including clams in the family Vesicomyidae, mussels in the genus Bathymodiolus, and worms in the family Siboglinidae, have also been found in hydrothermal vents and cold seeps (Glover et al. 2005). Given that cetacean carcasses create sulfidic conditions similar to other chemosynthetic habitats, the evolution of whales may have facilitated the dispersal and radiation of deep-sea fauna. About 25\% of seep genera first appeared in the Eocene along with the earliest oceanic whales (Kiel and Little 2006).

Because of their large body size and low mass-specific metabolism, in addition to the large number of sunken carcasses, great whales can efficiently transfer $\mathrm{C}$ from surface waters to the deep sea. Whale falls currently transfer an estimated 190000 tons $\mathrm{C} \mathrm{yr}^{-1}$ from the atmosphere to deeper waters (Pershing et al. 2010). The restoration of whale populations to historical numbers would lead to an increase in $\mathrm{C}$ export comparable in magnitude to the hypothetical Fe-fertilization (climate engineering) projects intended to mitigate climate change (Pershing et al. 2010).

Not all whale carcasses sink to the seafloor after death. Some are stranded on coastlines, thereby transporting marine biomass to the sea-land interface. Although the number of stranded whales is small as compared with those that sink (Smith 2006), carcasses can attract and nourish large terrestrial consumers, including bears and other predatory mammals and scavenging birds, as well as invertebrates such as flies and intertidal amphipods. Historically, these strandings were important to the diets 


\begin{tabular}{|c|c|}
\hline Service & Mechanism \\
\hline Enhanced primary productivity & $\begin{array}{l}\text {-Whale pump delivers limiting nutrients (Fe and } \mathrm{N} \text { ) to ocean surface, increasing photosynthesis } \\
\text { (eg Lavery et al. 20I0; Roman and McCarthy 20I0) } \\
\text { - Migrating whales bring nutrients in urine, carcasses, and placentas, from nutrient-rich temperate-subpolar } \\
\text { areas to the more oligotrophic regions where they breed }\end{array}$ \\
\hline $\begin{array}{l}\text { Enhanced biodiversity and } \\
\text { evolutionary potential }\end{array}$ & $\begin{array}{l}\text {-Whale falls provide habitat and nutrients for endemic and deep-sea species } \\
\text {-Whale falls also provide connectivity for hydrothermal-vent and cold-seep communities in the deep sea } \\
\text { (Smith 2006) }\end{array}$ \\
\hline Climate regulation & $\begin{array}{l}\text {-Whale pump delivers limiting nutrients ( } F e \text { and } N \text { ) to ocean surface, increasing } C \text { fixation } \\
\text { - } C \text { is sequestered through whale falls (Pershing et al. 20I0) }\end{array}$ \\
\hline Culture and conservation & $\begin{array}{l}\text {-Whales were among the first marine species to be protected by national and international laws, } \\
\text { - Whablishing precedents for ocean and endangered species legislation (Roman et al. 20I3) } \\
\text { - Stranding and fisheries-disentanglement responses promote stewardship and concern for the marine } \\
\text { environment at large } \\
\text { - Research and management programs provide seasonal industries in many communities } \\
\text { - Conflict over whaling has promoted a culture of protest and defiance (eg Greenpeace and Sea Shepherd) }\end{array}$ \\
\hline Tourism & -Whale watching is a global industry, valued at $\sim$ US $\$ 2$ billion per year (O’Connor et al. 2009) \\
\hline Provisioning & -Aboriginal and commercial whaling \\
\hline
\end{tabular}

of California condors (Gymnogyps californianus) and perhaps extinct scavengers. Today, with fewer whales and fewer available carcasses, the California condor has shifted to terrestrial food sources (Chamberlain et al. 2005), and this shift has contributed to its decline by reducing available resources and increasing the risk of poisoning from lead ammunition in game killed and lost or abandoned by hunters (Finkelstein et al. 2012).

\section{Whale recovery and ocean restoration}

Katona and Whitehead (1988) posited the question, "[would] the extinction of all cetaceans ... create any noticeable difference in ecosystem function"? We believe the evidence is now sufficient to confidently answer "yes". This warrants a shift in view from whales being positively valued as exploitable goods - or negatively valued because they compete with people for marine fish to one that recognizes that these animals play key roles in healthy marine ecosystems, providing services to human societies (Table 2). Although the contribution of whales to global fluxes of $\mathrm{C}$ and nutrients is relatively small, their effects on nutrient levels can be important to ecosystem function on local and regional scales: a pattern consistent with our emerging understanding of the role of animals in the $\mathrm{C}$ cycle (Schmitz et al. 2014). These (and very likely other) ecosystem services have been severely degraded by commercial whaling; recovering whale populations would help to restore them. As whale numbers rise, we may also see increased conflicts with human activities, such as predation on aquaculture and competition with fisheries, though a recent investigation of four coastal ecosystems has demonstrated the potential for large increases in whale abundance without major changes to existing food-web structures or substantial impacts on fishery production (Ruzicka et al. 2013).
What are the prospects for whale recovery? Current laws such as the US Marine Mammal Protection Act and the widespread reduction of commercial whaling have helped to achieve population increases in several whale species (Magera et al. 2013; Roman et al. 2013). Some populations, such as North Pacific humpbacks and southern right whales, are well on their way to recovering from industrial whaling. Others, such as North Atlantic right whales and Antarctic blue whales, were so reduced that they may be suffering from Allee effects, with individual fitness lowered because of small population size. Even without these effects, it could take decades or centuries for these species to return to historical abundances, if they ever do. In addition, modern oceans are changing in other ways that may affect recovery. Natural climate cycles have undoubtedly contributed to population fluctuations in the past, and while the future impact of such changes on particular whale species is difficult to predict, shifts in temperature and productivity are likely to influence all great whale populations. The suitable Arctic habitat of bowhead whales, for example, is predicted to be almost halved by the end of the 21 st century, which will surely influence future population dynamics (Foote et al. 2013). And although most countries have discontinued commercial whaling, many still effectively "whale" through direct impacts such as ship collisions and fishinggear entanglements and the indirect effects of ocean noise, loss of prey base, and the spread of disease (Davidson et al. 2012).

As some whale populations approach pre-harvest levels, we can expect to see a rise in associated ecosystem services along with conflicts, real and perceived, with human activities such as commercial fisheries. New field observations and an increased understanding of historical population dynamics are likely to provide evidence of undervalued whale ecosystem services. Expanded efforts 
in this area of research will improve estimates of the benefits - some of which, no doubt, remain to be discovered - of an ocean repopulated by the great whales.

\section{Acknowledgements}

Financial and logistical support was provided by the Gund Institute for Ecological Economics; research and financial support was provided to JR by the Marine Mammal Commission, Fulbright Scholar Program, and the Mary Derrickson McCurdy Visiting Scholar Program at the Duke University Marine Lab. AP was supported by the Lenfest Ocean Program of the Pew Charitable Trusts.

\section{References}

Alter SE, Rynes E, and Palumbi SR. 2007. DNA evidence for historic population size and past ecosystem impacts of gray whales. P Natl Acad Sci USA 104: 15162-67.

Amon DJ, Glover AG, Wiklund H, et al. 2013. The discovery of a natural whale fall in the Antarctic deep sea. Deep-Sea Res PT I 92: 87-96.

Apollonio S. 2002. Hierarchical perspectives in marine complexities: searching for systems in the Gulf of Maine. New York, NY: University of Columbia Press.

Baco AR and Smith CR. 2003. High species richness in deep-sea chemoautotrophic whale skeleton communities. Mar Ecol-Prog Ser 260: 109-14.

Ballance LT, Pitman RL, Hewitt R, et al. 2006. The removal of large whales from the Southern Ocean: evidence for long-term ecosystem effects. In: Estes JA, DeMaster DP, Doak DF, et al. (Eds). Whales, whaling and ocean ecosystems. Berkeley, CA: University of California Press.

Baum JK and Worm B. 2009. Cascading top-down effects of changing oceanic predator abundances. J Anim Ecol 78: 699-714.

Berge J, Gabrielson TM, Moline M, and Renaud PE. 2011. Evolution of the Arctic Calanus complex: an Arctic marine avocado? J Plankton Res 34: 191-95.

Bowen W. 1997. Role of marine mammals in aquatic ecosystems. Mar Ecol-Prog Ser 158: 267-74.

Branch TA and Williams TM. 2006. Legacy of industrial whaling. In: Estes JA, DeMaster DP, Doak DF, et al. (Eds). Whales, whaling and ocean ecosystems. Berkeley, CA: University of California Press.

Chamberlain CP, Waldbauer JR, Fox-Dobbs K, et al. 2005. Pleistocene to recent dietary shifts in California condors. P Natl Acad Sci USA 102: 16707-11.

Christensen LB. 2006. Marine mammal populations: reconstructing historical abundances at the global scale. Vancouver, Canada: University of British Columbia.

Costa DP. 2009. Energetics. In: Perrin WF, Wursig B, and Thewissen JGM (Eds). Encyclopedia of marine mammals. San Diego, CA: Academic Press.

Croll DA, Kudela R, and Tershy BR. 2006. Ecosystem impacts of the decline of large whales in the North Pacific. In: Estes JA, DeMaster DP, Doak DF, et al. (Eds). Whales, whaling and ocean ecosystems. Berkeley, CA: University of California Press.

Croll DA, Marinovic B, Benson S, et al. 2005. From wind to whales: trophic links in a coastal upwelling system. Mar EcolProg Ser 289: 117-30.

Davidson AD, Boyer AG, Kim H, et al. 2012. Drivers and hotspots of extinction risk in marine mammals. P Natl Acad Sci USA 109: 3395-400.

Dewar WK, Bingham RJ, Iverson RL, et al. 2006. Does the marine biosphere mix the ocean? J Mar Res 64: 541-61.

Estes J, Doak D, Springer A, and Williams T. 2009. Causes and con- sequences of marine mammal population declines in southwest Alaska: a food-web perspective. Phil Trans R Soc B 364: 1647-58.

Estes JA, Steneck RS, and Lindberg DR. 2013. Exploring the consequences of species interactions through the assembly and disassembly of food webs: a Pacific/Atlantic comparison. Bull Mar Sci 89: 11-29.

Estes JA, Terborgh J, Brashares JS, et al. 2011. Trophic downgrading of planet Earth. Science 330: 301-06.

Estes JA, Tinker MT, Williams TM, and Doak DF. 1998. Killer whale predation on sea otters linking oceanic and nearshore ecosystems. Science 282: 473-76.

Finkelstein ME, Doak DF, George D, et al. 2012. Lead poisoning and the deceptive recovery of the critically endangered California condor. P Natl Acad Sci USA 28: 11449-54.

Foote AD, Kaschner K, Schultze SE, et al. 2013. Ancient DNA reveals that bowhead whale lineages survived Late Pleistocene climate change and habitat shifts. Nature Comm 4: 1677.

Forney KA and Wade P. 2006. Worldwide distribution and abundance of killer whales. In: Estes JA, DeMaster DP, Doak DF, et al. (Eds). Whales, whaling and ocean ecosystems. Berkeley, CA: University of California Press.

Glover AG, Goetz E, Dahlgren TG, and Smith CR. 2005. Investigation of the morphology, reproductive biology and population genetics of the whale-fall and hydrothermal-vent specialist, Bathykurila guaymasensis Pettibone 1989 (Annelida: Polynoidae). Mar Ecol 26: 1-13.

Hain JH, Ellis SL, Kenney RD, et al. 1995. Apparent bottom feeding by humpback whales on Stellwagen Bank. Mar Mamm Sci 11: 464-79.

Hastings A, Byers JE, Crooks JA, et al. 2007. Ecosystem engineering in time and space. Ecol Lett 10: 153-64.

Jones $\mathrm{C}$ and Gutierrez J. 2007. On the purpose, meaning, and usage of the physical ecosystem engineering concept. In: Cuddington $\mathrm{K}$, Byers J, Wilson W, and Hastings A (Eds). Ecosystem engineers: plants to protists. Burlington, MA: Academic Press.

Katona S and Whitehead H. 1988. Are cetacea ecologically important? Oceanogr Mar Biol 26: 553-68.

Kiel S and Little CTS. 2006. Cold-seep mollusks are older than the general marine mollusk fauna. Science 313: 1429-31.

Lambert O, Bianucci G, Post K, et al. 2010. The giant bite of a new raptorial sperm whale from the Miocene Epoch of Peru. Nature 466: $105-08$.

Lavery TJ, Roudnew B, Gill P, et al. 2010. Iron defecation by sperm whales stimulates carbon export in the Southern Ocean. Proc $R$ Soc B 277: 3527-31.

Lavery TJ, Roudnew B, Seymour J, et al. 2014. Whales sustain fisheries: blue whales stimulate primary production in the Southern Ocean. Mar Mammal Sci; doi:10.1111/mms.12108.

Lavigne DM. 2003. Marine mammals and fisheries: the role of science in the culling debate. In: Gales N, Hindell M, and Kirkwood R (Eds). Marine mammals: fisheries, tourism, and management issues. Melbourne, Australia: CSIRO.

Lee CI, Pakhomov E, Atkinson A, and Siegel V. 2010. Long-term relationships between the marine environment, krill and salps in the Southern Ocean. J Mar Biol; doi:10.1155/2010/410129.

Lundsten L, Schlining KL, Frasier K, et al. 2010. Time-series analysis of six whale-fall communities in Monterey Canyon, California, USA. Deep-Sea Res PT I 57: 1573-84.

Magera AM, Mills Flemming JE, Kaschner K, et al. 2013. Recovery trends in marine mammal populations. PLoS ONE 8: e77908.

Markell RW. 2011. Rockfish recruitment and trophic dynamics on the west coast of Vancouver Island: fishing, ocean climate, and sea otters (PhD dissertation). Vancouver, Canada: University of British Columbia.

Morissette L, Christensen V, and Pauly D. 2012. Marine mammal impacts in exploited ecosystems: would large scale culling benefit fisheries? PLoS ONE 7: e43966.

Morissette L, Kaschner K, and Gerber LR. 2010. "Whales eat fish"? 
Demystifying the myth in the Caribbean marine ecosystem. Fish Fish 11: 388-404.

Nelson CH and Johnson KR. 1987. Whales and walruses as tillers of the sea floor. Sci Am 256: 112-17.

Nicol S, Bowie A, Jarman S, et al. 2010. Southern Ocean iron fertilization by baleen whales and Antarctic krill. Fish Fish 11: 203-09.

O'Connor S, Campbell R, Cortez H, and Knowles T. 2009. Whale watching worldwide: tourism numbers, expenditures and expanding economic benefits. Yarmouth, MA: Economists At Large and International Fund for Animal Welfare.

Pershing AJ, Christensen LB, Record NR, et al. 2010. The impact of whaling on the ocean carbon cycle: why bigger was better. PLOS ONE 5: e12444.

Pfister B and DeMaster DP. 2006. Changes in marine mammal biomass in the Bering Sea/Aleutian Island region before and after the period of industrial whaling. In: Estes JA, DeMaster DP, Doak DF, et al. (Eds). Whales, whaling and ocean ecosystems. Berkeley, CA: University of California Press.

Rabalais NN. 2002. Nitrogen in aquatic ecosystems. Ambio 31: $102-12$.

Rasmussen K, Palacios DM, Calambokidis J, et al. 2007. Southern Hemisphere humpback whales wintering off Central America: insights from water temperature into the longest mammalian migration. Biol Lett 3: 302-05.

Reeves RR, Berger J, and Clapham PJ. 2006. Killer whales as predators of large baleen whales and sperm whales. In: Estes JA, DeMaster DP, Doak DF, et al. (Eds). Whales, whaling and ocean ecosystems. Berkeley, CA: University of California Press.

Reilly SB, Bannister JL, Best PB, et al. 2008. Megaptera novaeangliae. IUCN Red List of Threatened Species Version 20131. www.iucnredlist.org. Viewed 23 Jun 2014.

Reisewitz SE, Estes JA, and Simenstad CA. 2006. Indirect food web interactions: sea otters and kelp forest fishes in the Aleutian archipelago. Oecologia 146: 623-31.

Roman J, Altman I, Dunphy-Daly MM, et al. 2013. The Marine Mammal Protection Act at 40: status, recovery, and future of US marine mammals. Ann NY Acad Sci; doi:10.1111/nyas.12040.

Roman J and McCarthy JJ. 2010. The whale pump: marine mammals enhance primary productivity in a coastal basin. PLoS ONE 5: e13255.

Roman J and Palumbi SR. 2003. Whales before whaling in the North Atlantic. Science 301: 508-10.

Ruegg K, Rosenbaum HC, Anderson EC, et al. 2013. Long-term population size of the North Atlantic humpback whale within the context of worldwide population structure. Conserv Genet 14: 103-14.
Ruzicka JJ, Steele JH, Ballerini T, et al. 2013. Dividing up the pie: whales, fish, and humans as competitors. Prog Oceanogr 116: 207-19.

Schmitz OJ, Raymon PA, Estes JA, et al. 2014. Animating the carbon cycle. Ecosystems 17: 344-59.

Sinclair A, Mduma S, and Brashares JS. 2003. Patterns of predation in a diverse predator-prey system. Nature 425: 288-90.

Smetacek V, Klaas C, Strass VH, et al. 2012. Deep carbon export from a Southern Ocean iron-fertilized diatom bloom. Nature 487: 313-19.

Smith CR. 2006. Bigger is better: the role of whales as detritus in marine ecosystems. In: Estes JA, DeMaster DP, Doak DF, et al. (Eds). Whales, whaling and ocean ecosystems. Berkeley, CA: University of California Press.

Smith LV, McMinn A, Martin A, et al. 2013. Preliminary investigation into the stimulation of phytoplankton photophysiology and growth by whale faeces. J Exp Mar Biol Ecol 446: 1-9.

Springer AM, Estes JA, Van Vliet G, et al. 2003. Sequential megafaunal collapse in the North Pacific Ocean: an ongoing legacy of industrial whaling? P Natl Acad Sci USA 100: 12223.

Springer AM, Estes JA, Van Vliet G, et al. 2008. Mammal-eating killer whales, industrial whaling, and the sequential megafaunal collapse in the North Pacific Ocean: a reply to critics of Springer et al. 2003. Mar Mammal Sci 24: 414.

Tønnessen JN and Johnsen AO. 1982. The history of modern whaling. Berkeley, CA: University of California Press.

Whitehead H. 2002. Estimates of current global population size and historical trajectory for sperm whales. Mar Ecol-Prog Ser 242: 295-304.

Wilmers CC, Estes JA, Edwards M, et al. 2012. Do trophic cascades affect the storage and flux of atmospheric carbon? An analysis for sea otters and kelp forests. Front Ecol Environ 10: 409-15.

Yool A, Martin AP, Fernandez C, and Clark DR. 2007. The significance of nitrification for oceanic new production. Nature 447: 999-1002.

${ }^{5}$ Department of Organismic and Evolutionary Biology, Harvard University, Cambridge, MA; ${ }^{6}$ Department of Mathematics, University of Hawaii, Honolulu, HI; ${ }^{7}$ Institute for Marine and Antarctic Studies, University of Tasmania, Tasmania, Australia; ${ }^{8}$ School of Marine Sciences, University of Maine, Orono, ME; ${ }^{9}$ Gulf of Maine Research Institute, Portland, ME; ${ }^{10}$ Alfred Wegener Institute, Helmholtz Centre for Polar and Marine Research, Bremerhaven, Germany

\section{TAKE THIS JOURNAL TO YOUR LIBRARIAN, PLEASE} Are you enjoying this issue of Frontiers?

If your library had a subscription, colleagues and students could enjoy it too. Please consider recommending Frontiers in Ecology and the Environment to your library. Clip or copy the form below. Thank you for your support.

Library Recommendation Form
To Acquisition Librarian, Serials
From
Dept
Signature _
I recommend the library subscribe to: Frontiers in Ecology and the Environment (ISSN 1540-9295)
To request a free sample issue of Frontiers in Ecology and the Environment, email Eric Gordon at eric@esa.org.
Order Frontiers by contacting ESA Headquarters at (202) 833-8773, online at www.esa.org, or through your subscription agent.

